\title{
HUBUNGAN STATUS PETANI \\ DAN KEBERLANJUTAN USAHATANI DENGAN \\ EKSISTENSI SUBAK DI KECAMATAN KUTA UTARA KABUPATEN BADUNG
}

\author{
The Correlation of Farmer's Status and Farming Business Continuity with Subak \\ Existence in North Kuta Sub-district, Badung Regency
}

\author{
Dewi Wulan Gentari, Nyoman Sutjipta, I Dewa Putu Oka Suardi
}

Program Studi Magister Agribisnis, Fakultas Pertanian, Universitas Udayana, Bali, Indonesia

E-mail: dewiwulangentari@gmail.com

\begin{abstract}
The need of land and water resources tends to increase due to the growth of population number, development importance, and the change of life style. Competition using land and water in the end will shift their availability for agriculture. Farmer's status and farming business continuity will measure subak existence in the middle of land need for non agriculture importance. This research purpose is to find out the correlation of farmer's status and farming business continuity with subak existence in North Kuta Sub-district. Research method uses the descriptive quantitative method. Respondent numbers are 60 farmer members which are collected in proportional random sampling. Data analysis technique uses the SEM-PLS analysis. Research results shows that farmer's status and farming business continuity has positive influence and it is very significant with the existence of subak. The indirect influence value which is the influence of farmer's status through the continuity of farming business is bigger than the direct influence. This proves that farmer's status is not yet maximal maintaining the existence of subak. Variable shaper indicator of farming business continuity has the highest value which means that the variable can be used as a benchmark in maintaining the existence of subak. Suggestion for Kramasubak in North Kuta Sub-district is that to be expected to be able to be more active in carrying out farming group activities that can help the economy. The implementer in agriculture field/academician can help to change farmer's mindset and can help in supplying the harvest to local villas or restaurants. The government can support to prepare rice plant shedding machine completed with the dryer.
\end{abstract}

Keywords: farmer's status, farming business continuity, subah existence

\begin{abstract}
ABSTRAK
Kebutuhan sumber daya lahan dan air cenderung meningkat karena pertumbuhan jumlah penduduk, kepentingan pembangunan, dan perubahan gaya hidup. Persaingan menggunakan lahan dan air pada akhirnya akan menggeser ketersediaan mereka untuk pertanian. Status petani dan keberlanjutan bisnis usahatani akan mengukur keberadaan subak di tengah kebutuhan lahan untuk kepentingan non pertanian. Penelitian ini bertujuan untuk mengetahui hubungan antara status petani dan kelangsungan usaha tani dengan keberadaan subak di Kecamatan Kuta Utara. Metode penelitian menggunakan metode deskriptif kuantitatif. Jumlah responden adalah 60 anggota petani yang dikumpulkan secara proporsional random sampling. Teknik analisis data menggunakan analisis SEM-PLS. Hasil penelitian menunjukkan bahwa status petani dan keberlanjutan bisnis usahatani memiliki pengaruh positif dan sangat signifikan dengan keberadaan subak. Nilai pengaruh tidak langsung yang merupakan pengaruh status petani melalui kelangsungan usaha pertanian lebih besar daripada pengaruh langsung. Ini membuktikan bahwa status petani belum maksimal mempertahankan keberadaan subak. Variabel pembentuk kontinuitas usaha usahatani memiliki nilai tertinggi yang berarti bahwa variabel tersebut dapat dijadikan patokan dalam mempertahankan keberadaan subak. Saran untuk Kramasubak di Kecamatan Kuta Utara adalah bahwa diharapkan dapat lebih aktif dalam melakukan kegiatan kelompok tani yang dapat membantu perekonomian. Pelaksana di bidang pertanian / akademisi dapat membantu mengubah pola pikir petani dan dapat membantu dalam memasok panen ke vila atau restoran lokal. Pemerintah dapat mendukung untuk menyiapkan mesin penggilingan padi yang dilengkapi dengan pengering.
\end{abstract}

Kata Kunci: status petani, keberlanjutan bisnis usahatani, keberadaan subak. 


\section{PENDAHULUAN}

\section{Latar Belakang}

Kebutuhan akan sumberdaya lahan dan air cenderung meningkat akibat pertambahan jumlah penduduk, kepentingan pembangunan, dan perubahan gaya hidup, sehingga kompetisi dalam pemanfaatannya juga semakin tajam baik antara sektor pertanian dengan sektor non pertanian maupun antar pengguna sektor pertanian itu sendiri. Persaingan penggunaan lahan dan air pada akhirnya akan menggeser ketersediaannya untuk pertanian. (Rai, 2011)

Alih fungsi lahan pertanian sulit dihindari akibat kecenderungan tersebut.Beberapa kasus menunjukkan jika di suatu lokasi terjadi alih fungsi lahan akibat tuntutan ekonomi, maka dalam waktu yang tidak lama lahan di sekitarnya juga beralih fungsi secara progresif.Salah satu dampak yang terlihat dari beralihnya fungsi lahan pertanian yaitu mulai menjamurnya pembangunan pemukiman penduduk, industri, pertokoan, dan pariwisata yang dibangun diatas lahan pertanian produktif.

Di daerah Kuta bagian utara, sektor pariwisata semakin mengejar untuk tersedianya fasilitas wisatawan yang memadai.Hasilnya lahan pertanian kembali dikorbankan untuk memenuhi hal tersebut.Bangunan villa, resort, cafe, hotel, home stay, dll sebagian besar berdiri di atas lahan pertanian yang produktif.

Laporan alih fungsi lahan sawah Kecamatan Kuta Utara tahun 2013 s.d 2015 menunjukkan dari 19 subak, terdapat 5 subak yang melakukan alih fungsi lahan terluas sejak tahun 2013 sampai dengan tahun 2015. Penyusutan lahan sawah selama tiga tahun terakhir terjadi karena alih fungsi lahan seluas 178.55 Ha. Saat alih fungsi lahan sawah terjadi, keberadaan subak yang menjadi warisan budaya dunia berlahan akan berkurang dan eksistensinya akan dipertanyakan. Hal inilah yang menarik minat peneliti untuk mencari hubungan status petani dan keberlanjutan usahatani dengan eksistensi subak di Kecamatan Kuta Utara.

\section{Rumusan Masalah}

Berdasarkan uraian latar belakang di atas, maka dapat dirumuskan permasalahannya sebagai berikut.

1. Bagaimana status petani pada subak di Kecamatan Kuta Utara?

2. Bagaimana keberlanjutan usahatani pada subak di Kecamatan Kuta Utara?

3. Bagaimana eksistensi subak di Kecamatan Kuta Utara?

4. Bagaimana hubungan status petani dan keberlanjutan usahatani dengan eksistensi subak di Kecamatan kuta Utara?

\section{Tujuan Penelitian}

Berdasarkan latar belakang dan rumusan masalah yang telah diuraikan, maka tujuan yang ingin dicapai dalam penelitian ini adalah untuk mengetahui

1. Status petani pada subak di Kecamatan Kuta Utara;

2. Keberlanjutan usahatani pada subak di Kecamatan Kuta Utara;

3. Eksistensi subak di Kecamatan Kuta Utara;

4. Hubungan status petani dan keberlanjutan usahatani dengan eksistensi subak di Kecamatan Kuta Utara.

\section{Kerangka Konsep Penelitian}

\section{Kerangka Konsep}

Permintaan pada lahan pertanian yang masih produktif sering terjadi pada beberapa daerah pariwisata yang sedang berkembang. Lahan pertanian dikorbankan karena permintaan dan tawaran yang menjanjikan kehidupan lebih baik bagi petani.Alih fungsi lahan terjadi dari berpindahnya kepemilikian lahan tersebut kepada investor. Kepemilikan lahan dapat berpindah umumnya dikarenakan petani tidak mampu lagi mengelola lahannya sendiri sehingga dijadikan sebagai warisan dan lokasi lahan terjepit oleh bangunan yang menyebabkan aliran air irigasi tidak lancar.Motivasi dalam melakukan alih fungsi lahan timbul karena ketidakpuasan petani terhadap pendapatan dibidang pertanian.Kebanyakan petani di daerah pariwisata berkembang membandingkan penghasilannya dengan pelaku dibidang pariwisata.Keinginan petani dalam melakukan alih fungsi lahan ditinjau berdasarkan status petani dan keberlanjutan usahatani.Status petani akan melihat pendapatan, lingkungan dan sosial petani. Keberlanjutan usahatani ditinjau berdasarkan kebijakan operasional, ketersediaan sarana dan prasaran serta pemasaran hasli panen.Motivasi alih fungsi lahan sawah akan mempengaruhi eksistensi subak karena jumlah lahan menurut fungsinya semakin menurun. Eksistensi subak akan dilihat setelah mengetahui status petani dan keberlanjutan usahatani yang terjadi di Kecamatan Kuta Utara. Eksistensi subak diukur berdasarkan lima fungsi subak. Lima fungsi subak tersebut adalah pencarian dan pendistribusian air irigasi, pemeliharaan jaringan irigasi, mobilisasi sumberdaya, pengelolaan (manajemen) konflik, dan pelaksanaan kegiatan ritual.

\section{METODE PENELITIAN}

\section{Lokasi dan Waktu Penelitian}

Penelitian ini dilakukan pada subak yang mengalami alih fungsi lahan terluas per tahun 2015 di kawasan Kecamatan Kuta Utara. Penelitian ini dilakukan mulai bulan Desember 2016 sampai Juli 2017 yang dimulai dari observasi lapangan, pengambilan sampel, uji kuesioner, dan pengambilan data pendukung penelitian. 


\section{Penentuan Populasi dan Sampel}

Populasi dalam penelitian ini adalah petani / anggota subak di Kecamatan Kuta Utara yang mengalami alihfungsi lahan.Dari 300 orang sebagai populasi, diambil $20 \%$ atau 60 orang dari anggota subak sebagai sample untuk dijadikan responden.

Teknik Pengumpulan Data, Variabel Penelitian, dan Metode Analisis

Metode pengumpulan data yang digunakan dengan teknik observasi, wawancara, dokumentasi. Variabel penelitian ini adalan status petani, keberlanjutan usahatani, dan eksistensi subak. Metode analisis yang digunakan adalah analisis deskriptif kuantitatif dan analisis Smart PLS.

Terdapat dua variabel eksogen, yaitu status petani $\left(\mathrm{X}_{1}\right)$ dan keberlanjutan usahatani $\left(\mathrm{X}_{2}\right)$. Variabel endogennya adalah eksistensi $\operatorname{subak}(\mathrm{Y})$. Variabelvariabel yang telah disampaikan merupakan variabel laten (unobserved) yang diukur dari beberapa indikator. Tiap-tiap indikator terdiri atas beberapa item yang dijabarkan dalam instrumen penelitian.Indikator pada status petani $\left(\mathrm{X}_{1}\right)$ terdiri dari status pendapatan petani $\left(\mathrm{X}_{1.1}\right)$, status lingkungan petani $\left(\mathrm{X}_{1 \cdot 2}\right)$, danstatus sosial $\left(\mathrm{X}_{1 \cdot 3}\right)$.Keberlanjutan usahatani $\left(\mathrm{X}_{2}\right)$ yang terdiri dari kebijakan operasional $\left(\mathrm{X}_{2.1}\right)$, ketersediaan sarana dan prasarana $\left(\mathrm{X}_{2.2}\right)$, pemasaran hasil panen $\left(\mathrm{X}_{2.3}\right)$. Eksistensi subak (Y)yang terdiri dari 5 indikator yaitu pencarian dan pendistribusian air irigasi $\left(\mathrm{Y}_{1}\right)$, pemeliharaan fasilitas $\left(\mathrm{Y}_{2}\right)$, mobilisasi sumberdaya $\left(\mathrm{Y}_{3}\right)$, pengelolaan (manajamen) konflik $\left(\mathrm{Y}_{4}\right)$, dan pelaksanaan kegiatan ritual $\left(\mathrm{Y}_{5}\right)$,selanjutnya dianalisis menggunakan SEM(PLS).

Evaluasi pada SEM $(P L S)$ terdiri atas evaluasi model pengukuran (outer model), evaluasi model struktural(inner model). Evaluasi model pengukuran (outer model) menunjukkan evaluasi pada convergent validity menunjukkan semua indikator memiliki nilai outer loading $>0,70$ dan nilai $t$ statistic > 2,66.Discriminant validity menunjukkan akar kuadrat AVE untuk setiap konstruk lebih besar dari korelasi antar konstruk dalam model. Composite reliability dan cronbach's alphamenunjukkan ketiga variabel laten memiliki nilai > 0,70. Evaluasi model pengukuran (outer model)menunjukkan indikator-indikator variabel laten yang ditelitimerupakan pengukur yang valid dan reliabel.

Evaluasi model struktural (inner model)menunjukkan bahwa keberlanjutan usahatani $\left(\mathrm{X}_{2}\right)$ memiliki nilai $R$-Square 0,449 hal ini berarti keadaan petani $\left(\mathrm{X}_{1}\right)$ mampu menjelaskan indikator keberlanjutan usahatani $\left(\mathrm{X}_{2}\right)$ sebesar $44,9 \%$. Eksistensi subak (Y) memiliki nilai $R$-Square 0,589 hal ini berarti status petani $\left(\mathrm{X}_{1}\right)$ dan keberlajutan usahatani $\left(\mathrm{X}_{2}\right)$ mampu menjelaskan eksistensi subak (Y) sebesar 58,9 \%. Evaluasi model struktural dengan melihat nilai $\mathrm{Q}^{2}$ sebesar0,773 $\left(\mathrm{Q}^{2}>0\right)$.Hasil evaluasi ini menunjukkan bahwa model struktural memiliki predictive relevance.Selanjutnya evaluasi model struktural dengan melihat nilai GoF (Goodness of Fit) menunjukkan nilai 0,730.Hasil evaluasi ini menunjukkan bahwa bahwa model struktural memiliki kesesuaian (goodness of fit model) yang baik. Hal ini berarti bahwa informasi yang terkandung dalam data $73 \%$ dapat dijelaskan oleh model sedangkan sisanya $27 \%$ dijelaskan variabel lain yang belum terdapat dalam model.

Pengujian hipotesis digunakan untuk menjawab hipotesis penelitian dan juga untuk mengetahui besarnya pengaruhmasing-masing variabel.Pengujian dilakukan dengan melihat nilai koefisien jalur dan $t$ statistik.Hasil pengujian hipotesis dapat dilihat pada Tabel 1.dibawah ini

\begin{tabular}{|c|c|c|c|}
\hline $\begin{array}{l}\text { Hubungan } \\
\text { Antar } \\
\text { Variabel }\end{array}$ & $\begin{array}{c}\text { Koefisien } \\
\text { Jalur }\end{array}$ & t-statistik & Keterangan \\
\hline $\begin{array}{l}\text { Status petani } \\
\left(\mathrm{X}_{1}\right)-> \\
\text { Eksistensi } \\
\text { subak }(\mathrm{Y})\end{array}$ & 0,432 & 4,042 & $\begin{array}{l}\text { Positif dan } \\
\text { sangat signifikan }\end{array}$ \\
\hline $\begin{array}{l}\text { Keberlanjutan } \\
\text { usahatani }\left(\mathrm{X}_{2}\right)- \\
\text { > Eksistensi } \\
\text { subak }(\mathrm{Y})\end{array}$ & 0,408 & 3,423 & $\begin{array}{l}\text { Positif dan } \\
\text { sangat signifikan }\end{array}$ \\
\hline $\begin{array}{l}\text { Status petani } \\
\left(\mathrm{X}_{1}\right) \text { - } \\
>\text { Keberlanjut } \\
\text { an usahatani } \\
\left(\mathrm{X}_{2}\right)\end{array}$ & 0,671 & 9,225 & $\begin{array}{l}\text { Positif dan } \\
\text { sangat signifikan }\end{array}$ \\
\hline
\end{tabular}

Sumber : Hasil Analisis Data Responden, 2017

Berdasarkan Tabel 4.12 diatas, dapat dinyatakan bahwa status petani $\left(\mathrm{X}_{1}\right)$ terhadap eksistensi subak $(\mathrm{Y})$, keberlanjutan usahatani $\left(\mathrm{X}_{2}\right)$ terhadap eksistensi subak $(\mathrm{Y})$ dan status petani $\left(\mathrm{X}_{1}\right)$ terhadap keberlanjutan usahatani $\left(\mathrm{X}_{2}\right)$ berpengaruh positif dan sangat signifikan yang ditunjukkan melalui nilai koefisien jalur yang bernilai positif dan t-statistik > 2,66 (alpha 1\%).

\section{HASIL DAN PEMBAHASAN}

\section{Variabel Status Petani}

Status petani digolongkan dalam tiga indikator yaitu status pendapatan petani, status lingkungan petani dan status sosial petani. Status petani mendapat kategori tingi dengan persentase $78,61 \%$ yang berarti bahwa pada keadaan empiris di lapangan dikatetgorikan rendah dan indikator yang mengukur berpergaruh terhadap eksistensi subak. Rendahnya keadaan empiris dilapangan, akan memicu munculnya motivasi terhadap alihfungsi lahan

Status pendapatan petani memperoleh persentase $87,44 \%$ dengan kategori sangat tinggi. Hal ini berarti status pedapatan petani adalah indikator yang paling berpengaruh terhadap eksistensi subak. Keadaan empiris di lapangan menyatakan bahwa status petani di golongkan rendah. Salah satu parameter yang mengukur status petani adalah kepemilikan aset petani yang tidak cukup untuk 
memeuhi kebutuhan keluarga. Pada variabel status petani, paramater inilah yang menunjukkan tingginya pengaruh indikator yang digunakan terhadap eksistensi subak.

Tabel 2. Status Petani di Kecamatan Kuta Utara

\begin{tabular}{lccc}
\hline & \multicolumn{3}{c}{ Status Petani } \\
\cline { 2 - 4 } & $\begin{array}{c}\text { Status } \\
\text { Pendapatan } \\
\text { Petani }\end{array}$ & $\begin{array}{c}\text { Status } \\
\text { Lingkungan } \\
\text { Petani }\end{array}$ & $\begin{array}{l}\text { Status } \\
\text { Sosial } \\
\text { Petani }\end{array}$ \\
\hline $\begin{array}{l}\text { Persentase } \\
\text { Pencapaian }\end{array}$ & 87,44 & 75,44 & 72,94 \\
$\begin{array}{l}\text { Skor(\%) } \\
\text { Kategori } \\
\text { Variabel }\end{array}$ & Sangat & Cukup & Cukup \\
\hline $\begin{array}{l}\text { Persentase } \\
\text { Pencapaian } \\
\text { Skor (\%) }\end{array}$ & & 78,61 & \\
\hline $\begin{array}{l}\text { Kategori } \\
\text { Status }\end{array}$ & & Tinggi & \\
Petani & & & \\
\hline Sumber : data diolah dari hasil survei, 2017
\end{tabular}

\section{Variabel Keberlanjutan Usahatani}

Keberlanjutan usahatani pada penelitian ini memiliki tiga indikator diantaranya kebijakan operasional, ketersediaan sarana dan prasarana, serta pemasaran hasil panen. Keberlanjutan usahatani memperoleh persentase sebesar $73,06 \%$ degan kategori tinggi yang berarti bahwa pada keadaan empiris di lapangan dikatetgorikan rendah dan indikator yang mengukur berpergaruh terhadap eksistensi subak. Rendahnya keadaan empiris dilapangan, akan memicu munculnya motivasi terhadap alihfungsi lahan

Tabel 3. Keberlanjutan Usahatani

\begin{tabular}{lccc}
\hline & \multicolumn{3}{c}{ Keberlanjutan Usahatani } \\
\cline { 2 - 4 } & $\begin{array}{c}\text { Kebijakan } \\
\text { Operasionl }\end{array}$ & $\begin{array}{c}\text { Ketersediaan } \\
\text { Sarana dan } \\
\text { Prasarana }\end{array}$ & $\begin{array}{c}\text { Pemasaran } \\
\text { Hasil Panen }\end{array}$ \\
\hline $\begin{array}{l}\text { Persentase } \\
\text { Pencapaian }\end{array}$ & 72,61 & 73,33 & 73,22 \\
$\begin{array}{l}\text { Skor (\%) } \\
\text { Kategori } \\
\text { Variabel }\end{array}$ & Tinggi & Tinggi & Tinggi \\
\hline $\begin{array}{l}\text { Persentase } \\
\text { Pencapaian } \\
\text { Skor (\%) }\end{array}$ & & 73,06 & \\
\hline $\begin{array}{l}\text { Kategori } \\
\text { Status } \\
\text { Petani }\end{array}$ & & Tinggi & \\
\hline Sumber : data diolah dari hasil survei, 2017 &
\end{tabular}

Sumber : data diolah dari hasil survei, 2017

Ketersediaan sarana dan prasaran memperoleh persentase 73,33\% dengan kategori tinggi. Hal ini berarti ketersediaan sarana dan prasarana adalah indikator pada variabel keberlanjutan usahatani yang paling berpengaruh terhadap eksitensi subak. Keadaan empiris di lapangan menyatakan bahwa keberlanjutan usahatani di golongkan rendah. Salah satu parameter yang mengukur keberlanjutan usahatani adalah tidak tersedianya lantai jemur. Pada variabel keberlanjutan usahatani, paramater inilah yang menunjukkan tingginya pengaruh indikator yang digunakan terhadap eksistensi subak.

\section{Eksistensi Subak}

Eksistensi subak diukur berdasarkan efektifnya fungsi subak yang dijalankan oleh petani atau anggota subak lainnya. Lima fungsi subak tersebut diantaranya pencarian dan distribusi air irigasi, pemeliharaan fasilitas, mobilisasi sumberdaya, pengelolaan (manajemen) konflik, dan pelaksanaan kegiatan ritual. Eksistensi subak memperoleh persentase sebesar 64,39\% dengan kategori cukup yang berarti bahwa keadaan empiris cukup dan indikator yang digunakan belum pasti memberi pengaruh terhadap eksistensi subak. Keadaan empiris di lapangan menunjukkan bahwa indikator yang digunakan untuk mengukur eksistensi subak belum pasti memberi pengaruh terhadap tinggi rendahnya eksistensi pada subak.

Mobilisasi sumberdaya memperoleh persentase sebesar $64,39 \%$ dengan kategori cukup. Hal ini berarti mobilisasi sumberdaya adalah indikator pada variabel eksistensi subak yang paling berpengaruh terhadap tinggi atau rendahnya eksitensi pada subak. Salah satu parameter yang mengukur eksistensi subak adalah krama subak banyak menjadikan lahannya sebagai warisan sehingga luas garapannya semakin berkurang. Pada variabel eksitensi subak, paramater inilah yang menunjukkan tingginya pengaruh indikator yang digunakan terhadap eksistensi subak.

\section{Hubungan Status Petani dan Keberlanjutan Usahatani dengan Eksistensi Subak Di Kecamatan Kuta Utara}

Hubungan motivasi alih fungsi lahan sawah terhadap eksistensi subak di Kecamatan Kuta Utara dapat dilihat melalui hasil uji statistik sebagaimana ditampilkan pada Gambar 1

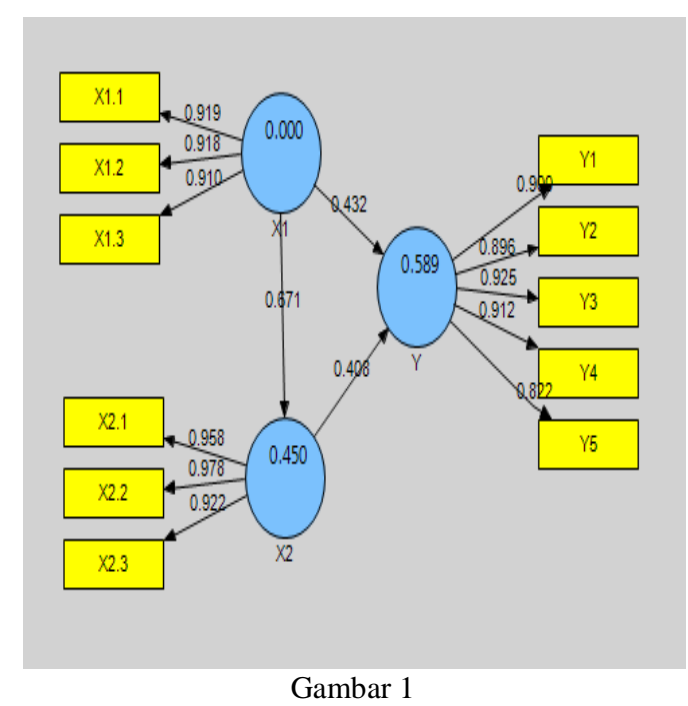

Model Struktural 
Berdasarkan Gambar 1. dapat diketahui nilai tertinggi dari variable status petani adalah indikator status pendapatan petani yang memiliki nilai sebesar $(0,919)$.Nilai tertinggi dari variable keberlanjutan usahatani adalah indikator ketersediaan sarana dan prasaranayang memiliki nilai sebesar $(0,978)$.Nilai tertinggi dari variable eksistensi subak adalah indikator mobilisasi sumberdaya yang memiliki sebesar $(0,925)$

\section{Pengaruh status petani terhadap eksistensi subak di Kecamatan Kura Utara}

Berdasarkan hasil analisis yang diperoleh melalui penelitian ini dinyatakan bahwa status petani $\left(\mathrm{X}_{1}\right)$ terbukti berpengaruh positif dan sangat signifikan terhadap eksistensi subak (Y). Hal ini dapat ditunjukkan oleh koefisien jalur yang bernilai positif sebesar 0,432 dengan t-statistik sebesar 4,042 atau tstatistik > 2,66.

Hasil penelitian ini menunjukan bahwa status petani sebagai salah satu indikator yang memberi pengaruh terhadap eksistensi subak. Tinggi rendahnya status petani akan memberi pengaruh terhadap eksistensi subak di Kecamatan Kuta Utara. Ketika status petani lemah, maka eksistensi subak semakin susah untuk dipertahankan karena lemahnya status petani akan memicu terjadinya alih fungsi lahan sehingga luas garapan subak secara otomatis akan berkurang.

Pengaruh keberlanjutan usahatani terhadap eksistensi subak di Kecamatan Kuta Utara

Keberlanjutan usahatani $\left(\mathrm{X}_{2}\right)$ terbukti berpengaruh positif dan sangat signifikan terhadap eksistensi subak (Y). Hal ini dapat ditunjukkan oleh koefisien jalur yang bernilai positif sebesar 0,408 dengan tstatistik sebesar 3,423 atau t-statistik > 2,66.

Keputusan ini diambil dengan alasan bahwa keberlanjutan usahatani sebagai keseluruhan pola dan tingkah laku petani dalam mengelola lahan pertanian sampai dengan menghasilkan produksi yang kemudian dapat dijual berpengaruh sangat signifikan terhadap eksistensi subak.

\section{Simpulan dan Saran Simpulan}

Berdasarkan hasil dan pembahasan dalam penelitian ini, maka kesimpulan yang didapat sebagai berikut.

1. Status petani pada penelitian ini diketegorikan tinggi. Hal ini berarti indikator yang digunakan untuk mengukur status petani berpengaruh tinggi terhadap eksistensi subak. Indikator yang memberi pengaruh tinggi adalah status pendapatan petani ketika diukur melalui pernyataan kepemilikan aset petani untuk kebutuhan keluarga.

2. Keberlanjutan usahatani pada penelitian ini dikategorikan tinggi. Hal ini berarti indikator yang digunakan untuk mengukur keberlanjutan usahatani berpengaruh tinggi terhadap eksistensi subak. Indikator yang memberi pengaruh tinggi adalah ketersediaan sarana dan prasana ketika diukur melalui pernyataan tidak tersedianya lantai jemur.

3. Eksistensi subak pada penelitian ini dikategorikan cukup. Hal ini berarti indikator yang digunakan untuk mengukur eksistensi subak belum dapat dipastikan mampu mempertahankan subak untuk tetap eksis. Indikator yang memberi pengaruh tinggi adalah mobilisasi sumberdaya ketika diukur melalui pernyataan bahwa krama subak banyak menjadikan lahannya sebagai warisan sehingga luas garapannya semakin berkurang.

4. Hubungan status petani dan keberlanjutan usahatani dengan eksistensi subak berpengaruh positif dan sangat signifikan. Masing-masing variabel tersebut memiliki indikator dengan pernyataan yang menjadi pemicu rendahnya eksistensi subak. Berdasarkan analisis Smart PLS, variabel keberlanjutan usahatani memperoleh nilai paling tinggi yang berarti variabel tersebut dapat digunakan sebagai tolak ukur dalam menjaga eksistensi subak

\section{Saran}

Berdasarkan hasil analisis dan pembahasan yang telah dilakukan dalam penelitian ini, maka dapat diberikan beberapa saran sebagai berikut.

1. Krama subak di Kecamatan Kuta Utara diharapkan mampu lebih aktif dalam melakukan kegiatan kelompok tani yang dapat membantu perekonomian.

2. Pelaksana di bidang pertanian / akademisi dapat membantu mengubah pola pikir petani yang terpaku pada produksi padi dan dapat membantu untuk melakukan suplay hasil panen ke villa atau restoran setempat.

3. Pemerintah dapat membantu menyediakan mesin perontok padi yang sertai dengan pengeringnya

\section{Ucapan Terima kasih}

Melalui e-jurnal ini saya menyampaikan ucapan terima kasih yang tulus kepada pengurus dan anggota subak yang terlibat dengan penuh perhatian dan memberikan dukungan berupa informasi dan pengalaman, sehingga saya dapat menyelesaikan ejurnal ini dengan baik.

\section{Daftar Pustaka}

BPS Kabupaten Badung. 2015. Badung Dalam Angka 2015. BPS Kabupaten Badung.

Ghozali, I. 2012. Structural Equation Modeling Metode Alternatif dengan Partial Least Square.Edisi 3. Universitas Diponegoro, Semarang.

Irawan. .2005. Alih Fungsi Lahan dalam Perspektif Lingkungan Perdesaan. http://pustaka.litbang.deptan.go.id Diunduh tanggal 23 Agustus 2016. 
Irawan. .2006. Multi Fungsi Lahan dan Revitalisasi Pertanian. Balai Penelitian Tanah. Balai Besar Litbang Sumber Daya Pertanian, dalam Surat Kabar Pembaharuan. http://pustaka.litbang.deptan.go.id Diunduh tanggal 23 Agustus 2016.

Laporan Data Alih Fungsi Lahan UPTD Pertanian Kecamatan Kuta Utara Tahun 2015.

Mardikanto, T. 1993. Penyuluhan Pembangunan Pertanian. UNS Press. Surakarta.

Rai. 2011. Persaingan Pemanfaatan Lahan dan Air.Udayana University Press. Denpasar.

Rianse.. 2012. Metode Penelitian Sosial dan Ekonomi : Teori dan Aplikasi. Alfabeta Bandung.

Siregar, S. 2013. Statistik Parametrik untuk Penelitian Kuantitatif. PT. Bumi Aksara, Jakarta

Sutejo. 2006. Analisis Kebijakan Pertanian. http://www.ejornal.ipb.ac.id Diunduh tanggal 15 Oktober 2016. 